International Journal of Market Research, Volume 55, Issue 2, Pages 227-246

\title{
Towards a Better Measure of Customer Experience
}

\section{Philipp Klaus and Stan Maklan}

Defining and improving customer experience is a growing priority for market research because experience is replacing quality as the competitive battleground for marketing. Service quality, we argue, is an outgrowth of the Total Quality Management movement of the 1980s and suffers from that movement's focus on the provider rather than the value derived by customers. The most popular measure of service quality - SERVQUAL - assesses the functional delivery of service during a single episode. This conceptualisation allows service to be improved along traditional quality management principles. The increasingly settled view of researchers is that customer experience is generated through a longer process of company-customer interaction across multiple channels and is generated through both functional and emotional clues. Research with practitioners indicates that most firms use customer satisfaction, or its derivative Net Promoter Score, to assess their customers' experiences. We question this practice based on the conceptual gap between these measures and the customer experience. In the IJMR October 2011, we proposed the principles of a new measure appropriate for the modern conceptualisation of customer experience: the Customer Experience Quality (EXQ) scale. In this article we extend that work to four service contexts to support a claim of generalisability better and compare its predictive power with that of customer satisfaction. We propose that EXQ better explains behavioural intention and recommendation than customer satisfaction.

\section{The background}

In our article asking if market researchers were using the right measures to help their firms improve customer experience, we established that customer experience was conceptually different from service quality and hence requires a new corresponding measurement (Klaus \& Maklan, 2007). The role of measurement in successfully implementing and executing strategy is long established and well documented (e.g. Martilla \& James 1977). This role is particularly crucial for new emerging paradigm shifts (Bowden 2009) such as the most recent one towards customer experience management (Smith 2002).

Based on research and literature, we defined customer experience as: the customer's cognitive and affective assessment of all direct and indirect encounters with the firm relating to their purchasing behaviour. This definition is highly consistent with conceptualisations offered by other researchers (e.g. Lemke et al. 2010, Verhoef et al. 2009).

Our interpretation of the literature generated the core tenants of a measure for customer experience (Maklan \& Klaus 2011):

1. It is assessed as an overall perception by customers and not as a gap to expectations. 
2. Customers' assessment is based on overall value in use and not just a summation of performance during individual service episodes.

3. The measure of experience has a broader scope than that proposed by SERVQUAL. It includes emotions and peer influences.

4. Experience begins before service encounters and continues after the encounters.

5. Experience is assessed against service encounters across all channels.

6. An ideal measure should link more directly to customer behaviour and business performance than do either SERVQUAL or customer satisfaction.

We presented EXQ, a scale measure of customer that explains important marketing outcomes (Maklan \& Klaus 2011). We illustrated that it incorporates key attributes of customer experience that are not captured in current market research assessments of service quality or customer satisfaction. EXQ allows tracking both of customer experience and its key attributes over time and can act as an important marketing metric.

Readers and managers commenting upon the article ask two main questions: (1) is EXQ generalisable beyond the context we presented, and (2) does it add to our current research practice based largely upon customer satisfaction and its derivative Net Promoter Score? This paper presents a synthesis of four contexts in which we validated EXQ to address issues of generalisability and assesses EXQ's explanatory power against customer satisfaction.

The rest of the paper is structured as follows. Next we respond to readers and managers by developing the hypotheses that address their questions. Then we introduce the method to address these aims. Finally we present and discuss our findings, including research contributions, managerial implications and suggestions for future research.

\section{Hypotheses development}

This paper focuses on the impact of customer experience on important marketing outcomes, namely customer satisfaction, loyalty and word-of-mouth behaviour. We chose these outcomes based on the weight of research suggesting their importance as outcomes (e.g. Puccinelli et al. 2009).

Scholars posit customer experience as a key determinant of customer satisfaction and loyalty (e.g. Caruana 2002). Customer experience and satisfaction, while discrete constructs (Garbarino \& Johnson 1999), are connected through a contributory relationship (Fornell 1992). Researchers suggest experience drives satisfaction, which in turn drives loyalty (e.g. Shankar et al. 2003). Marketing scholars acknowledge the link between satisfaction and loyalty intentions (Yi \& La 2004). The exact nature of this relationship is still questioned because improved customer satisfaction is a desirable, but not sufficient, condition for affecting behavioural intentions (McDougall \& Levesque 2000). Therefore we explore the influence of customer experience on customer satisfaction and loyalty intentions independently.

Customer experience not only drives customer satisfaction (e.g. Anderson \& Mittal 
2000) and loyalty (Fornell et al. 2006), but also word-of-mouth (Keiningham et al. 2007). The influence of customer experience on word-of-mouth (recommendation) is discussed widely in traditional offline media (Babin et al., 2005), online (e.g. HennigThurau et al. 2002) and experiential settings (e.g. Voss \& Zomerdijk 2007). Subsequently, we explore the proposed relationship between customer experience and word-of-mouth.

We believe, based on our synthesis of the literature, that experience has a more significant impact than satisfaction on customer loyalty and word-of-mouth (e.g. Koenig-Lewis \& Palmer 2008). That customer satisfaction has a positive influence on behavioural loyalty intentions (e.g. Gremler \& Brown 1996), and between customer satisfaction and word-of-mouth (e.g. Brown et al. 2005) has been researched widely. Therefore we refrain from stating hypotheses between these constructs.

Based on literature, we developed the following hypotheses (see Figure 1):

Hypothesis 1: Customer experience has a significant positive impact on customer satisfaction.

Hypothesis 2: Customer experience has a significant positive impact on loyalty intentions ${ }^{1}$.

Hypothesis 3: Customer experience has a significant positive impact on word-ofmouth behaviour.

Hypothesis 4: Customer experience has a more significant positive impact on loyalty intentions than customer satisfaction.

Hypothesis 5: Customer experience has a more significant positive impact on wordof-mouth behaviour than customer satisfaction.

In this paper, we validated a customer experience quality scale (EXQ) that can be readily adapted by different types of service providers. In order to develop and validate a customer experience quality scale capable of serving this purpose, we adopted and extended the validated Silvestro et al. (1992) service classification scheme. We chose one high value service (mortgages), one mass service (fuel and service station) and one "utility" service (retail banking). In addition, we included one service reflecting the hedonic nature of customer experiences: lifestyle luxury goods retail. The latter service was chosen to ensure further cross-validation (Cronin et al. 2000), so that samples varied on the degree to which the service could be characterised as hedonic (lifestyle luxury goods) versus utilitarian (fuel and service station). The context for the research was the UK, although most of the firms operate internationally.

We adopted Klaus and Maklan's (2012) Customer Experience Quality (EXQ) scale to validate our hypotheses about the impact of customer experience quality and its impact on important marketing outcomes, namely customer satisfaction, loyalty and word-of-mouth behaviour, as suggested and defined by Brown et al. (2005), Dagger et al. (2007), Parasuraman et al. (2005), Walsh and Beatty (2007) and Zeithaml et al. (1996). A full description of the corresponding measures is provided in Appendix 1.

\footnotetext{
${ }^{1}$ As defined and measured by Zeithaml et al. 1996
} 
In the 2011 article, we introduced a scale measure of customer experience - EXQ whose dimensions are product experience, outcome focus, moments-of-truth and peace-of-mind (POMP). Product experience refers to the importance of customers' perception of having choices and the ability to compare offerings, a critical factor in modelling consumer behaviour (McAlister \& Srivastava 1991) and antecedent of loyalty (Srinivasan et al. 1998). Outcome focus is associated with reducing customers' transaction cost, such as seeking out and qualifying new providers, reflecting the importance of goal-oriented experiences in consumer behaviour (Huffman \& Houston 1993). Moments-of-truth emphasizes the importance of service recovery (Tax et al. 1998) and flexibility (Liljander \& Strandvik 1993) in dealing with customers once complications arise. Peace-of-mind describes the customer's assessment of all the interactions with the service provider before, during and after the purchase of the service. This dimension includes statements strongly associated with the emotional aspects of service (Klaus \& Maklan 2011; Edvardsson 2005). The full list of attributes for each dimension is provided in Appendix 1. The authors are happy to share further data of method, questionnaire, results and attendant validity testing with interested readers.

We collected the data as follows:

- Mortgage customers: an online questionnaire accessible through a link sent by a market research firm to a sample of customers of a UK bank who had purchased their most recent mortgage within the previous six months.

- Fuel and service station customers: an online questionnaire accessible through a link sent by a market research firm to a sample of customers in their customer database, split between first time and repeat customers.

- Retail banking customers: a printed questionnaire, distributed to customers of the retail bank, split between first time and repeat customers.

- Luxury goods customers: an online questionnaire accessible through a link sent by a market research firm to a sample of customers who had purchased items with the service provider within the previous three months, split between first time and repeat customers.

Respondents rated their customer experience on each scale item using a 7-point scale $(1=$ Strongly disagree, $7=$ Strongly agree $)$ or as Do not know/Not applicable. The items were grouped by dimensions for expositional convenience; they appeared in random order on the survey. The symbols preceding the items correspond to the variables named in Figure 1 (see Appendix 1). The corresponding survey generated 800 qualified responses (200 responses per context), which were subsequently analysed utilising the software packages SPSS 16.0 and AMOS 16.0. Appendix 2 contains descriptive profiles of the exploratory stage of each context. Before running the structural model, we examined whether the four samples could be pooled or demanded three separate analyses. The results of the multigroup comparison confirmed configural invariance (CFI 0.97; RMSEA 0.05) and factor loading equivalence (CFI 0.97; RMSEA 0.05; with an insignificant change in chi-square of 8.9/df 997). These values indicate metric invariance, which implies that the three samples represent the same general population (Hair et al. 1998). Therefore, we proceeded with an analysis based on pooled data (see Table 1). The response bias analysis (Armstrong \& Overton 1977) provided evidence that non-response was not a concern in this study. Managers in the individual companies reviewed the 
demographic profiles of the respondent samples and confirmed that they were representative of their customer base.

The fit of the measurement and structural models examined was assessed through multiple indices, as recommended by Hoyle and Panter (1995). It has been suggested that a Chi-square value two or three times as large as the degrees of freedom is acceptable (Carmines \& McIver 1981), but the fit is considered better the closer the Chi-square value (CMIN) is to the degrees of freedom (df) for a model (Thacker et al. 1989). EXQ's CMIN/df ratio displays an excellent fit. Measures of incremental fit were used as indicators of acceptable model fit. The scale statistics (see Table 2) indicate the robustness of the EXQ model (Garver \& Mentzer 1999; Hoyle and Panter 1995) on the basis of the fit criteria established in prior service quality research (Parasuraman et al. 2005).

The psychometric properties of the scale were evaluated through a comprehensive Confirmatory Factor Analysis (CFA). All items were tested in the same model and were restricted to load on their respective factors. The results are a sign of high levels of construct reliability and average variance extracted for all latent variables. All $t$ values were significant $(p=0.05)$, and the average variances extracted were $>0.50$, and thus convergent validity was established. Using Fornell's and Larcker's (1981) stringent criteria for measuring the internal consistency of a scale and its ability to measure a latent construct, we establish construct reliability with estimates exceeding 0.50 (see Table 3 ).

After establishing the strength and psychometric properties of the scales underpinning the model, we examined the structure of the model. We modelled customer experience as suggested by researchers as a formative construct in which the dimensions of the model drive customer experience perceptions (Parasuraman et al. 2005). In addition, we conducted second-order CFAs in which the dimensions of EXQ (e.g. peace-of-mind) were specified as reflective indicators of a second-order overall customer experience (EXQ) construct. The CFA analysis and model fit statistics were analogous to those reported in this study. On the basis of these criteria, we modelled our measurement reflectively (see Figure 1). Therefore, the confirmatory factor analysis (CFA) results reported are for first-order factor models specifying the scale items as reflective indicators of their corresponding latent constructs, and allow the latent constructs to intercorrelate.

To establish nomological validity, we examined how well the EXQ scale relates to other variables. Thus, in addition to the EXQ scale, the questionnaire included a fiveitem Behavioural Loyalty Scale (Parasuraman et al. 2005) based on a 13-item battery developed by Zeithaml et al. (1996); adapted a 5-item Customer Satisfaction scale (Dagger et al. 2007); and incorporated a 7-item Word-of-Mouth Behaviour scale (Brown et al. 2005). These measures (see Appendix B) allow us to capture the full range of potential behaviours likely to be triggered by customer experience (Mascarenhas et al. 2006). To demonstrate that a measure has nomological validity, the correlation between the measure and other related constructs should behave as expected in theory (Churchill 1995). The reliability of these scales was assessed with a composite reliability coefficient (ranging from 0.92 to 0.97 ) and CFA, which clearly confirmed the appropriateness of the operationalisations (see Table 4). 


\section{Results of hypothesis testing}

Model fit and structural parameters for the service experience, satisfaction, loyalty and word-of-mouth paths are illustrated in Table 5. A closer inspection of these results shows that customers' experience perceptions have a large influence on customer satisfaction for all services (0.65), indicating that two-thirds of the variance in customer satisfaction was explained by the customer experience, supporting Hypothesis 1. Customer experience also had a significant impact on loyalty intentions (0.59). Thus, Hypothesis 2 was also supported. Customer experience also displays a positive and considerable influence on word-of-mouth behaviour (0.63), supporting Hypothesis 3. Similarly, customer satisfaction was found to influence significantly the customers' behavioural intentions (0.57) and word-of-mouth behaviour (0.46) for all services, supporting Hypotheses 4 and 5. When considering the direct and indirect effects in the model, customer experience was found to have a greater total effect on loyalty intentions and a significantly higher positive impact on word-of-mouth behaviour than customer satisfaction. Indirect effects were analysed by modelling customer satisfaction as a mediator between customer experience and outcomes (see Table 5). All our hypotheses are, therefore, confirmed (see Table 6). Examination of the structural parameters indicates that product experience, outcome focus, momentsof-truth and peace-of-mind have a significant and positive impact on customer satisfaction, loyalty and word-of-mouth behaviour. In fact, moments-of-truth and peace-of-mind have the greatest effect on customer satisfaction, loyalty and word-ofmouth behaviour. Peace-of-mind seems to have the highest effect on customer satisfaction (0.37) and word-of-mouth (0.39). Moments-of-truth had an important effect on customer satisfaction (0.34) and word-of-mouth behaviour (0.32), also to a lesser extent than peace-of-mind. Moments-of-truth demonstrates the highest effect of all dimensions on loyalty intentions (0.37).

\section{Discussion}

In this research, we undertook a large study across four service settings to gain a better understanding of the construct of customer experience and its influence on important marketing outcomes. The study is extensive in terms of exploring a range of consumer behaviour across three different services, including multiple service episodes, multiple channels and a variety of service classifications (Silvestro et al. 1992). Managing the customer experience is considered one of today's most complex and pressing issues for service organizations globally (e.g. Badgett et al. 2007). This study examines the impact of the service experience on important marketing outcomes comprehensively. The findings have implications for theory and practice, as we now discuss.

Customer experience is a key determinant of consumer behaviour and an important strategic objective for service firms. Customers' perceptions of their experience are generally associated with the question of how service is delivered rather than exploring what is delivered (Goldstein et al. 2002), and how the customer experience relates to important marketing outcomes (Klaus \& Maklan 2012). The study addresses 
these gaps by delivering evidence defining the exact nature of customer experience and its significant positive influence on customer satisfaction, word-of-mouth and loyalty.

Our findings confirm that all four dimensions of customer experience quality have a positive and significant impact on important marketing outcomes, validating the notion that the customer experience evaluation goes beyond the direct service encounter, and includes direct and indirect encounters with all organizational functions of the organization and possible channels and touch points, such as marketing communications, advertising, internet presence and after-sales care (e.g. Payne et al. 2008; Voss et al. 2008). This suggests consumers' evaluation of experience goes beyond the direct service encounter, and includes direct and indirect encounters with all touch points, such as marketing communications, advertising, internet presence and after-sales care (e.g. Payne et al. 2008). Investigating the influence of each individual dimension on the outcomes, the results show that product experience and outcome focus have almost equally significant influence on all outcomes. The dimension peace-of-mind has the most significant influence of all dimensions on customer satisfaction and word-of-mouth. This dimension reflects the emotional benefits customers experience based on the perceived expertise of the service provider (Bendapudi \& Berry 1997) and guidance throughout the process (Dabholkar et al. 1996), leading to the notion of building "a relationship" with a service provider (Geyskens et al. 1996). The dimension moments-of-truth has the greatest influence on word-of-mouth behaviour, confirming prior research (e.g. Maxham 2001). This dimension is highly relevant because of its close link to direct interactions and the resulting customer experiences with the service company. The findings suggest the importance of past experiences with the service company in forming positive behavioural intentions (Voss \& Zomerdijk 2007) and influencing loyalty (e.g. Buttle \& Burton 2002).

EXQ allows managers to monitor the dimensions and attributes of the customer experience that link to customers' assessment of satisfaction, loyalty and positive word-of-mouth behaviour. EXQ thus allows managers to understand how their customers evaluate the different dimensions and attributes of their customer experience by linking them to important marketing outcomes. After all, a company must first understand the triggers of this behaviour and its importance to the outcomes in order to improve its customer experience, establishing a close link to revenue.

Moreover, customer experience measures (e.g. EXQ) should be considered alongside more traditional means of assessing strategy - customer satisfaction and Net Promotor Score - as they may be better and more direct predictors of consumer behaviour.

The findings put forward in this study demonstrate a stronger relationship between customer experience and loyalty than between customer satisfaction and loyalty. For that reason the findings posit the presence of an at least equal, but possibly more direct link between service evaluations and behavioural intentions through the construct of customer experience. Consequently, the study advocates customer experience as an alternative, and possibly even better, validated predictor of consumer behaviour. These findings are in line with studies suggesting there might be constructs capable of predicting loyalty better than customer satisfaction (e.g. Koenig-Lewis \& Palmer 2008). 
Word-of-mouth is considered an important consumer behaviour for several reasons (Day 1980). For example, word-of-mouth communication provides face-to-face, often explicit, information that is highly credible (Brown et al. 2005). This information can influence others' beliefs about a company and their offerings, subsequently altering consumers' intentions to purchase from the company and offering in question (Lutz 1975; Sheth \& Parvatiyar 1995). Researchers offer satisfaction, and dissatisfaction, as antecedents to word-of-mouth (recommendation) (Yi 1990). This study establishes the significant positive impact of customer experience on word-of-mouth and a stronger relationship than customer satisfaction. The findings indicate customer experience as not only one of the possible antecedents, but the most significant antecedent of word-of-mouth.

EXQ can be used by managers to determine which strategies and practices will have the most positive influence on customers' perceptions and behaviour. The study connects the customer's evaluation of the service in a more direct way than traditional key marketing scales, such as customer satisfaction, to loyalty and word-of-mouth. This allows organizations to improve their customer experience management. The study therefore not only establishes a more direct link between organizations' marketing efforts and behaviour, but could also increase their understanding of the link between marketing and financial performance.

\section{Limitations and directions for future research}

Although this study is comprehensive, it is not without its limitations. Firstly, the use of loyalty intention is well supported in the literature. Ultimately one would wish to conduct a test with observed (verifiable) actual purchase behaviour in a longitudinal study. The study examines services in just one country. Replication of our research in other countries would enable us to generalise the results and develop an even stronger theory. The study focuses on four different service settings based on a widely cited and validated service typology. Other researchers may wish to investigate even more hedonic consumption services, such as entertainment or tourism. Moreover, it would be beneficial to explore if and how the customer experience perceptions change between first-time, returning, regular customers and over time. Another avenue of exploration is into the possible influence of encounters with similar service providers on the customer experience perception with the current main service provider. Scholars suggest that customer experience affects business performance, and future research should determine how customer experience explains and influences important marketing outcomes such as market share, share of wallet and ultimately profitability. 


\section{References}

Anderson, E.W. \& Mittal, V. (2000) Strengthening the satisfaction-profit chain. Journal of Service Research, 3, 2, pp. 107-120.

Armstrong, J.S. \& Overton, T. (1977) Estimating nonresponse bias in mail surveys. Journal of Marketing Research, 14, pp. 396-402.

Babin, B.J., Lee, Y.-K., Kim, E.-J. \& Griffin, M. (2005) Modeling consumer satisfaction and word-of-mouth: restaurant patronage in Korea. Journal of Services Marketing, 19, 3, pp. 133-139.

Badgett, M., Moyce, M.S. \& Kleinberger, H. (2007), Turning shoppers into advocates, IBM Institute for Business Value.

Bendapudi, N. \& Berry, L. (1997) Customers' motivations for maintaining relationships with service providers. Journal of Retailing, 73, pp. 15-37.

Bowden, J. L.-H. (2009) The process of customer engagement: a conceptual framework. Journal of Marketing Theory and Practice, 17, 1, pp. 63-74.

Brown, T.J., Barry, T.E., Dacin, P.A. \& Gunst, R.F. (2005) Spreading the word: investigating the antecedents of consumers' positive word-of-mouth intentions and behaviors in a retailing context. Journal of the Academy of Marketing Science, 33, 2, pp. 123-138.

Buttle, F. \& Burton, J. (2002) Does service failure influence customer loyalty? Journal of Consumer Behavior, 1, 3, pp. 217-227.

Carmines, E.G. \& McIver, J. (1981) Analysing models with unobserved variables: Analysis of covariance structures, in Bohmstedt, G. and Borgatta, E. (Eds), Social Measurement: Current Issues. Beverly Hills, CA: SAGE, pp. 65-115.

Caruana, A. (2002) Service loyalty: the effects of service quality and the mediating role of customer satisfaction. European Journal of Marketing, 36, 7/8, pp. 811-829.

Churchill, G.A., Jr. (1995), Marketing Research Methodological Foundations, 6th ed. Fort Worth, TX: Dryden Press.

Cronin, J.J., Brady, M.K. \& Hult, G.T.M. (2000) Assessing the effects of quality, value and customer satisfaction on consumer behavioral intentions in service environments. Journal of Retailing, 76, 2, pp. 193-218. 
Dabholkar, P., Thorpe, D. \& Rentz, J. (1996) A measure of service quality for retail stores: scale development and validation. Journal of the Academy of Marketing Science, 24, 1, pp. 3-16.

Dagger, T., Sweeney, J. \& Johnson, L. (2007) A hierarchical model of health service quality: scale-development and investigation of an integrated model. Journal of Service Research, 10, 2, pp. 123-142.

Edvardsson, B. (2005) Service quality: beyond cognitive assessment. Managing Service Quality, 15, 2, pp. 127-31.

Fornell, C. (1992) A national customer satisfaction barometer: the Swedish experience. Journal of Marketing, 56, 1, pp. 6-21.

Fornell, C. \& Larcker, D. (1981) Evaluating structural equation models with unobservable variables and measurement error. Journal of Marketing Research, 18, 1, pp. 39-50.

Fornell, C., Mithas, S.F.V.M. \& Krishnan, M.S. (2006) Customer satisfaction and stock prices: high returns, low risk. Journal of Marketing, 70, 1, pp. 3-14.

Garbarino, E. \& Johnson, M.S. (1999) The different roles of satisfaction, trust, and commitment in customer relationships. Journal of Marketing, 63, 2, pp. $70-87$.

Garver, M.S. \& Mentzer, J.T. (1999) Logistics research methods: employing structural equation modeling to test for construct validity. Journal of Business Logistics, 20, 1, pp. 33-57.

Gebauer, H., Fleisch, E. \& Friedli, T. (2005) Overcoming the service paradox in manufacturing companies”. European Management Journal, 23, 1, pp. 14-26.

Geyskens, I., Jan-Benedict, E., Steenkamp, M., Scheer, L. \& Kumar, N. (1996) The effects of trust and interdependence on relationship commitment: a trans-atlantic study. International Journal of Research in Marketing, 13, 4, pp. 303-317.

Goldstein, S.M., Johnston, R., Duffy, J. \& Rao, J. (2002) The service concept: the missing link in service design research? Journal of Operations Management, 20, 2, pp. 121-134.

Gremler, D. \& Brown, S.W. (1996) Service loyalty: its nature, importance, and implications, in Edvardsson, B. (Eds), Advancing Service Quality: A Global Perspective. International Service Quality Association, pp. 171-180.

Hair, J., Anderson, R., Tatham, R. \& Black, W. (1998) Multivariate Data Analysis. Upper Saddle River, NJ: Prentice Hall International.

Hennig-Thurau, T., Gwinner, K.P. \& Gremler, D.D. (2002) Understanding relationship marketing outcomes. Journal of Service Research, 4, 3, pp. 230-247.

Hoyle, R. \& Panter, A. (1995) Writing about structural equation models, in R. Hoyle 
(Ed.), Structural Equation Modeling. Thousand Oaks, CA: SAGE, pp. 158-176.

Huffman, C. \& Houston, M. (1993) Goal-oriented experiences and the development of knowledge. Journal of Consumer Research, 20, 2, pp. 190-207.

Keiningham, T.L., Cooil, B., Aksoy, L., Andreassen, T.W. \& Weiner, J. (2007) The value of different customer satisfaction and loyalty metrics in predicting customer retention, recommendation and share-of-wallet. Managing Service Quality, 17, 4, pp. 361-384.

Klaus, Ph. and Maklan, S. (2007) The role of brands in a service dominated world. Journal of Brand Management, 15, 2, pp. 115-122.

Klaus, Ph. and Maklan, S. (2011). Bridging the gap for destination extreme sports - a model of sports tourism customer experience. Journal of Marketing Management, 27, 13-14, pp. 1341-1365.

Klaus, Ph. \& Maklan, S. (2012) EXQ: a multiple-scale for assessing service experience. Journal of Service Management, 23, 1.

Koenig-Lewis, N. \& Palmer, A. (2008) Experiential values over time - a comparison of measures of satisfaction and emotion. Journal of Marketing Management, 24, 1, pp. 69-85.

Lemke, F., Clark, M. \& Wilson, H. (2010) Customer experience quality: an exploration in business and consumer contexts using Repertory Grid Technique. Journal of the Academy of Marketing Science, 39, 6, pp. 846-869.

Liljander, V. \& Strandvik, T. (1993) Estimating zones of tolerance in perceived service quality and perceived service value. International Journal of Service Industry Management, 4, 2, pp. 6-28.

Lutz, R.J. (1975) Changing brand attitudes through modification of cognitive structure. Journal of Consumer Research, 1 (March), pp. 49-59.

Maklan, S. \& Klaus, Ph. (2011) Customer Experience: Are we measuring the right things. International Journal of Market Research, 53, 6, pp. 771-792.

Martilla, J. A., \& James, J. C. (1977) Importance-performance analysis. Journal of Marketing, 41, 1, pp. 77-79.

Maxham, J. G., III. (2001) Service recovery's influence on consumer satisfaction, positive word-of-mouth and purchase intentions. Journal of Business Research, 54, 1, pp. 11-24.

McAlister, L. \& Srivastava, R. (1991) Incorporating choice dynamics in models of consumer behaviour. Marketing Letters, 2, 3, pp. 241-252. 
McDougall, G.H.G. \& Levesque, T. (2000) Customer satisfaction with services: putting perceived value into the equation. Journal of Services Marketing, 14, 4/5, pp. 392-410.

Parasuraman, A., Zeithaml, V. \& Malhotra, A. (2005) E-S-QUAL: a multiple-item scale for assessing electronic service quality. Journal of Service Research, 7, 3, pp. 213-234.

Payne, A., Storbacka, K. \& Frow, P. (2008) Managing the co-creation of value. Journal of the Academy of Marketing Science, 36, 1, pp. 83-96.

Puccinelli, M.N., Goodstein, C.R., Grewal, D., Price, R., Raghubir, P. \& Stewart, D. (2009) Customer experience management in retailing: understanding the buying process. Journal of Retailing, 85, 1, pp. 15-30.

Shankar, V., Smith, A.K. \& Rangaswamy, A. (2003) Customer satisfaction and loyalty in online and offline environments. International Journal of Research in Marketing, 20, 2, pp. 153-175.

Sheth, J.N. \& Parvatiyar, A. (1995) Relationship marketing in consumer markets: antecedents and consequences. Journal of the Academy of Marketing Science, 23, 4, pp. 255-271.

Silvestro, R., Fitzgerald, L., Johnston, R. \& Voss, C. (1992) Towards a classification of service processes. International Journal of Service Industry Management, 3, 3, pp. $62-75$.

Smith, S. \& Milligan, A. (2002) Uncommon Practice: People who deliver a great brand experience. Financial Times Prentice Hall.

Srinivasan, S., Anderson, R. \& Kishore, P. (1998) Customer loyalty in e-commerce: An exploration of its antecedents and consequences. Journal of Retailing, 78, 1, pp. 41-50.

Tax, S., Brown, S. \& Chandrashekaran, M. (1998) Consumer evaluations of service complaint experiences: implication for relationship marketing. Journal of Marketing, 62, pp. 60-76.

Thacker, J.W., Fields, M.W. \& Tetrick, L.E. (1989) The factor structure of union commitment: an application of confirmatory factor analysis. Journal of Applied Psychology, 74, 2, pp. 228-232.

Verhoef, P., Lemon, K., Parasuraman, A., Roggeveen, A., Tsiros, M. \& Schlesinger, L. (2009) Customer experience creation: determinants, dynamics and management strategies. Journal of Retailing, 85, 1, pp. 31-41.

Voss, C. \& Zomerdijk, L. (2007) Innovation in experiential services - an empirical view, in Innovation in Services. London: DTI, pp. 97-134.

Voss, C., Roth, A. V., \& Chase, R. B. (2008) Experience, service operations strategy, and services as destinations: Foundations and exploratory investigation. Production 
and Operations Management, 17, pp. 247-266.

Walsh, G. \& Beatty, S. (2007) Customer-based corporate reputation of the service firm: scale development and validation. Journal of the Academy of Marketing Science, 35, 1, pp. 127-143.

Yi, Y. (1990) A critical review of consumer satisfaction, in Zeithaml, V. (Ed.) Review of Marketing, Vol. 4. Chicago, IL: American Marketing Association, pp. 68-123.

Yi, Y. \& La, S. (2004) What influences the relationship between customer satisfaction and repurchase intention? Investigating the effects of adjusted expectations and customer loyalty. Psychology and Marketing, 21, 5, pp. 351-373.

Zeithaml, V., Berry, L. \& Parasuraman, A. (1996) The behavioral consequences of service quality. Journal of Marketing, 60, 2, pp. 31-46. 


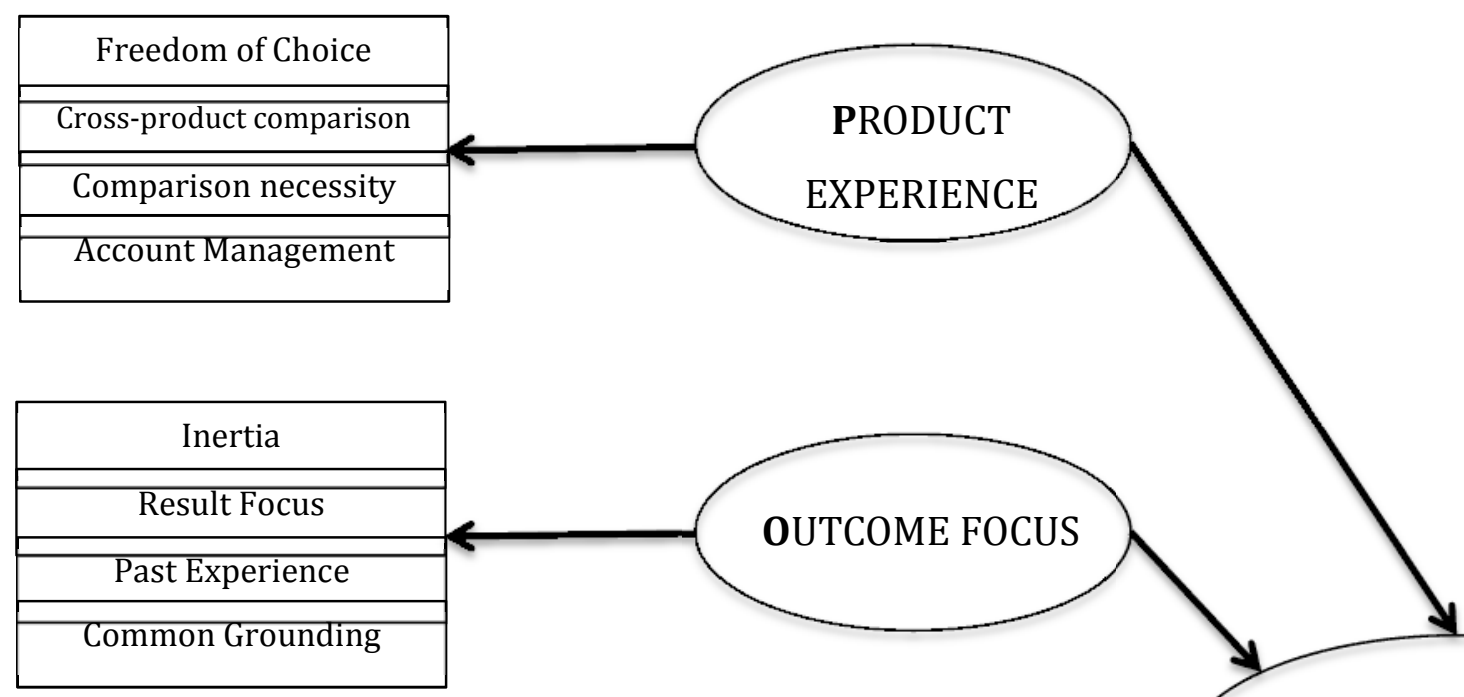

\begin{tabular}{|c|}
\hline Flexibility \\
\hline Pro-activity \\
\hline Risk Perception \\
\hline Interpersonal Skills \\
\hline Service Recovery \\
\hline
\end{tabular}

\section{CUSTOMER}

\section{EXPERIENCE}

\begin{tabular}{|c|}
\hline Expertise \\
\hline Process Ease \\
\hline Relationship/Transactio \\
\hline Convenienee retention \\
\hline \hline Familiarity \\
\hline Independent Advice \\
\hline
\end{tabular}

MOMENTS-OF-TRUTH

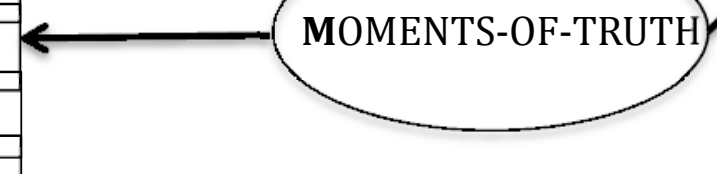

Figure 1 Conceptual model customer experience quality 
Table 1 Results multigroup analysis

$\begin{array}{lllll}\text { Model } & \text { df } & \text { CMIN } & \text { CFI } & \text { RMSEA } \\ \begin{array}{l}\text { Factor } \\ \text { structure }\end{array} & 174 & 36.422 & 0.97 & 0.05 \\ \begin{array}{l}\text { equivalence } \\ \begin{array}{l}\text { Factor loading } \\ \text { equivalence }\end{array}\end{array} & 246 & 240.864 & 0.97 & 0.05\end{array}$


Table 2 Measurement reliability and validity

Measurement

Customer experience quality (EXQ)

Customer satisfaction

Word-of-mouth

Loyalty intentions

Primary EXQ dimensions

Product experience

Outcomes focus

Moments-of-truth

Peace-of-mind

Goodness-of-fit indices

\section{Construct} reliability

0.932379

0.960334

0.980842

0.881302

0.800019

0.822325

0.850427

0.903719

CMIN

1179
Average variance extracted

0.903793

0.915345

0.922636

0.844210

0.767217

0.780963

0.800014

0.824560

CFI IFI RMSEA

$\begin{array}{lll}0.96 & 0.96 & 0.06\end{array}$ 
Table 3 EXQ construct reliability analysis

Dimension

Peace-of-mind

(composite reliability 0.90 )

Moments-of-truth (0.85)

Outcome focus (0.82)

Product experience (0.80)
Item

PEA1

PEA2

PEA3

PEA4

PEA5

PEA6

MOM1

MOM2

MOM3

MOM4

MOM5

OUT1

OUT2

OUT3

OUT4

PRO1

PRO2

PRO3

PRO4

\section{Construct reliability}

score

0.888

0.704

0.533

0.620

0.619

0.522

0.783

0.711

0.784

0.555

0.619

0.654

0.606

0.584

0.546

0.579

0.644

0.891

0.778 
Table 4 Scale reliability test marketing outcomes

Measurement

CR AVE

Loyalty intentions (Parasuraman et al. 2005; Zeithaml et al. 1996)

$0.94 \quad 0.84$

L1 Say positive things about XYZ to other people?

0.96

L2 Recommend XYZ to someone who seeks your advice? 0.88

L3 Encourage friends and relatives to use XYZ? 0.91

L4 Consider XYZ the first choice to buy - services?

L5 Use XYZ more in the next few years? 0.92

Customer satisfaction (Hubbert 1995; Oliver 1997) 0.96

0.89

SAT1 My feelings towards XYZ are very positive.

0.94

SAT2 I feel good about coming to XYZ for the offerings I am 0.93

looking for.

SAT3 Overall I am satisfied with XYZ and the service they provide. $\quad 0.97$

SAT4 I feel satisfied that XYZ produce the best results that can be $\quad 0.82$

achieved for me.

SAT5 The extent to which XYZ has produced the best possible $\quad 0.83$

outcome for me is satisfying.

Word-of-mouth behaviour (Brown et al. 2005) 0.94

0.84

WOM1 Mentioned to others that you do business with XYZ. 0.91

WOM2 Made sure that others know that you do business with XYZ. 0.92

WOM3 Spoke positively about XYZ employee(s) to others. 0.96

WOM4 Recommended XYZ to family members. $\quad 0.92$

WOM5 Spoke positively of XYZ to others. 0.95

$\begin{array}{ll}\text { WOM6 Recommended XYZ to acquaintances. } & 0.93\end{array}$

WOM7 Recommended XYZ to close personal friends. $\quad 0.90$

AVE Average variance extracted; CR composite reliability 
Table 5 Standard path estimates

Hypothesis $1 \quad$ EXQ $\rightarrow$ Customer satisfaction

0.643432

Product experience $\rightarrow$ EXQ

0.213342

Outcomes focus $\rightarrow$ EXQ

0.222731

Moments-of-truth $\rightarrow$ EXQ

0.341962

Peace-of-mind $\rightarrow$ EXQ

0.372811

0.586358

Hypothesis $2 \quad E X Q \rightarrow$ Loyalty intentions

0.184652

Product experience $\rightarrow$ EXQ

0.229765

Outcomes focus $\rightarrow$ EXQ

0.366894

Moments-of-truth $\rightarrow$ EXQ

0.314586

Peace-of-mind $\rightarrow$ EXQ

0.625133

Hypothesis $3 \quad E X Q \rightarrow$ Word-of-mouth

0.216179

Product experience $\rightarrow$ EXQ

0.256947

Outcomes focus $\rightarrow$ EXQ

0.319646

Moments-of-truth $\rightarrow$ EXQ

0.389441

Hypothesis $4 \quad$ Customer satisfaction $\rightarrow$ Loyalty

0.577697

intentions

$0.565214 \rightarrow 0.572124$

Loyalty intentions

Hypothesis 5 Customer satisfaction $\rightarrow$ Word-

0.455463

of-mouth

EXQ $\rightarrow$ Customer satisfaction $\rightarrow$

Word-of-mouth

Goodness-of-fit indices

CMIN df CFI IFI RMSEA

$\begin{array}{lllll}1263 & 799 & 0.96 & 0.96 & 0.06\end{array}$


Table 6 Hypothesis confirmation

\begin{tabular}{|l|l|l|l|}
\hline Hypothesis & $\begin{array}{l}\text { Customer Experience has a } \\
\text { significant positive impact } \\
\text { upon... }\end{array}$ & Confirmation & $\begin{array}{l}\text { Evidence (Path estimate } \\
\text { scores) }\end{array}$ \\
\hline 1 & Customer Satisfaction & Yes & Path estimate of 0.64 \\
\hline 2 & Loyalty & Yes & Path estimate of 0.59 \\
\hline 3 & Word-of-Mouth & Yes & Path estimate of 0.63 \\
\hline & $\begin{array}{l}\text { Customer Experience has a } \\
\text { higher positive impact than } \\
\text { customer satisfaction upon... }\end{array}$ & & \\
\hline 4 & Loyalty & Yes & $\begin{array}{l}0.59 \text { versus } 0.58 \text { (direct) and } \\
0.57 \text { (indirect) }\end{array}$ \\
\hline 5 & Word-of-Mouth & Yes & $\begin{array}{l}0.63 \text { versus } 0.46 \text { (direct) and } \\
0.35 \text { (indirect) }\end{array}$ \\
\hline
\end{tabular}


Appendices

\section{Appendix 1: Measures of study constructs}

\section{EXQ}

Respondents rated their customer experience on each scale item using a 7-point scale ( 1 = strongly disagree, $7=$ strongly agree) or as Do not know/Not applicable. The items below are grouped by dimensions for expositional convenience; they appeared in random order in the survey.

\section{Peace of mind}

PEA1 I am confident in XYZ's expertise.

PEA2 The whole process with XYZ was easy.

PEA3 XYZ will look after me for a long time.

PEA4 I stay with XYZ because of my past dealings with XYZ.

PEA5 I have dealt with XYZ before so getting what I needed was really easy.

PEA6 XYZ give(s) independent advice.

\section{Moments-of-truth}

MOM1 XYZ was flexible in dealing with me and looked out for my needs.

MOM2 XYZ keeps me up-to-date.

MOM3 XYZ is a safe and reputable company.

MOM4 The people at XYZ have good people skills.

MOM5 XYZ deal(t) with me correctly when things go (went) wrong.

\section{Outcome focus}

OUT1 Staying with XYZ makes the process much easier.

OUT2 XYZ gives me what I need swiftly.

OUT3 I prefer XYZ over an alternative provider.

OUT4 The people at XYZ can relate to my situation.

\section{Product experience}

PRO1 I need to choose between different options at XYZ.

PRO2 I need to receive offers from more than just XYZ.

PRO3 I need to compare different options from XYZ.

PRO4 I have one designated contact at XYZ. 
Customer satisfaction (e.g. Dagger et al., 2007)

Respondents rated each item using a 7-point scale $(1=$ strongly disagree, $7=$ strongly agree) or as Do not know/Not applicable.

SAT1 My feelings towards XYZ are very positive.

SAT2 I feel good about coming to XYZ for the offerings I am looking for.

SAT3 Overall I am satisfied with XYZ and the service they provide.

SAT4 I feel satisfied that XYZ produce the best results that can be achieved for me.

SAT5 The extent to which XYZ has produced the best possible outcome for me is satisfying.

Behavioural loyalty intentions (Parasuraman et al., 2005; Zeithaml et al., 1996)

Respondents rated their likelihood on each scale item using a 7-point scale ( $1=$ not at all likely, 7 = extremely likely) or as Do not know/Not applicable. The items below were grouped as outlined below on the survey.

L1 Say positive things about XYZ to other people?

L2 Recommend XYZ to someone who seeks your advice?

L3 Encourage friends and relatives to use XYZ?

L4 Consider XYZ the first choice to buy - services?

L5 Use XYZ more in the next few years?

Word-of-mouth behaviour (Brown et al., 2005)

Respondents rated "How often they did the following" on each scale item using a 7point scale $(1=$ never, $7=$ frequently $)$ or as Do not know/Not applicable. The items below were grouped by dimensions as outlined below on the survey.

WOM1 Mentioned to others that you do business with XYZ.

WOM2 Made sure that others knew that you do business with XYZ.

WOM3 Spoke positively about XYZ employee(s) to others.

WOM4 Recommended XYZ to family members.

WOM5 Spoke positively of XYZ to others.

WOM6 Recommended XYZ to acquaintances.

WOM7 Recommended XYZ to close personal friends. 
Appendix 2: Sample profiles used in EFA ${ }^{2}$

\begin{tabular}{|c|c|c|c|c|}
\hline \multirow{2}{*}{$\begin{array}{l}\text { Variable } \\
\text { Age: } \\
\text { Under } 18\end{array}$} & Professional service & Mass service & Service shop & Hedonic service \\
\hline & - & 3.00 & - & 2.00 \\
\hline $18-24$ & 5.00 & 8.00 & 9.00 & 8.00 \\
\hline $25-34$ & 31.00 & 28.00 & 26.00 & 31.00 \\
\hline $35-44$ & 26.00 & 28.00 & 27.00 & 25.00 \\
\hline $45-54$ & 20.00 & 18.00 & 22.00 & 19.00 \\
\hline $55-64$ & 16.00 & 12.00 & 11.00 & 10.00 \\
\hline $65+$ & 2.00 & 3.00 & 5.00 & 5.00 \\
\hline \multicolumn{5}{|l|}{ Gender: } \\
\hline Male & 64.00 & 64.00 & 62.00 & 60.00 \\
\hline Female & 36.00 & 36.00 & 38.00 & 40.00 \\
\hline $\begin{array}{l}\text { Educational } \\
\text { background: } \\
\text { high school or } \\
\text { less }\end{array}$ & 32.00 & 32.00 & 36.00 & 30.00 \\
\hline Some college & 48.00 & 36.00 & 38.00 & 38.00 \\
\hline College graduate & 12.00 & 14.00 & 18.00 & 47.00 \\
\hline Graduate school & 8.00 & 8.00 & 8.00 & 10.00 \\
\hline $\begin{array}{l}\text { Annual } \\
\text { household } \\
\text { income (growth } \\
\text { in US\$):Up to } \\
\$ 20000\end{array}$ & 3.00 & 4.00 & 3.00 & 4.00 \\
\hline $\begin{array}{l}\$ 20001 \text { to } \\
\$ 45000\end{array}$ & 21.00 & 22.00 & 18.00 & 16.00 \\
\hline $\begin{array}{l}\$ 45001 \text { to } \\
\$ 75000\end{array}$ & 19.00 & 24.00 & 22.00 & 18.00 \\
\hline $\begin{array}{l}\$ 75000 \text { to } \\
\$ 125000\end{array}$ & 30.00 & 27.00 & 28.00 & 30.00 \\
\hline $\begin{array}{l}\$ 125000 \text { to } \\
\$ 250000\end{array}$ & 23.00 & 19.00 & 25.00 & 26.00 \\
\hline $\begin{array}{l}\text { More than } \\
\$ 250000\end{array}$ & 4.00 & 4.00 & 4.00 & 6.00 \\
\hline
\end{tabular}

\footnotetext{
${ }^{2}$ Numbers did not sum to 100 in all instances and are rounded to the next digit before .00 for expositional convenience.
} 
Prof. Dr. Philipp "Phil” Klaus

Professor of Customer Experience and Marketing Strategy

ESCEM School of Business and Marketing

Correspondence Address: Via San Sebastiano 3317020 Tovo San Giacomo (SV)

Italia

E-mail: dr.philipp.klaus@ gmail.com Telephone: +39 (0)3498876196

Dr Philipp "Phil" Klaus is Professor of Customer Experience and Marketing Strategy at ESCEM School of Business and Management, France, Visiting Fellow at Cranfield University School of Management and holds visiting professorships at LUMSA University in Rome, Italy and the University of Valencia in Spain. His areas of expertise include customer experience strategy and management, customer experience quality, marketing strategy, the influence of marketing activities and customer experience on consumer behaviour and the financial performance of organizations. Phil is a frequent keynote speaker at public and in-company seminars and conferences around the world. He is an experienced senior marketing manager and management consultant with an active, international portfolio of Blue Chip clients from the financial services, retail, luxury goods and the energy sectors, for whom he advises on customer experience strategy, profit enhancement, customer behaviour, best practice and business development.

Dr Stan Maklan (s.maklan@cranfield.ac.uk) is Senior Lecturer in Strategic Marketing at the Cranfield University School of Management. Prior to joining academe, Stan had 20 years' senior, international experience with blue-chip organisations in consumer marketing, marketing services and IT management consulting. Stan established the UK CRM practice for a world leader in IT services. His research interests are dynamic capability development, CRM, customer experience, organisational brand development and marketing accountability. 